doi: 10.19090/i.2020.31.217-231

UDC: 821.163.41.09 Rajčević M.

\author{
UROŠ MATIĆ \\ Austrian Academy of Sciences \\ Austrian Archaeological Institute \\ uros.matic@oeai.at
}

\title{
A POSTCOLONIAL PERSPECTIVE OF A VOYAGE TO EGYPT IN THE TRAVELOGUE UNDER THE AFRICAN SUN BY MILORAD RAJČEVIĆ*
}

\begin{abstract}
Milorad Rajčević (1890-1964), a famous Serbian traveller, adventurer, and travelogue writer, also went to Egypt in 1921 as part of his world travels. Impressions and experiences from his travels were published consecutively in Belgrade magazine Little Journal and in the form of monographs Under the African Sun (1924 and 1925) and In the Far East (1930). These writings provide us with an important insight into the Serbian bourgeois class image of both ancient Egypt and Egypt in the time Rajčević made his journey. His impressions and experiences from Egypt were transmitted through his travelogue Under the African Sun and were shaped by colonial discourse of a European traveller. It provides us with an insight into the attitudes towards ancient and modern Egypt before academic interest in studying ancient Egyptian past in Serbia. The travelogue contains numerous Orientalist ideas about Arabic population of Egypt. From the point of view of history of archaeology, particularly important are his comments on progress and modernisation. In that context, his comparisons of European with Ancient Egyptian cultural and technical achievements play a significant role. This paper analyses the content of the travelogue Under the African Sun from a postcolonial perspective and argues that although certain ideas inherent to colonial episteme of his time can be recognized, it is not possible to pinpoint the exact sources Rajčević used.

Keywords: Milorad Rajčević, travelogue, Egypt, Arabs, orientalism, postcolonial perspective.
\end{abstract}

\section{Introduction}

A cademic interest in studying ancient Egyptian past appeared in Serbia relatively late in comparison to the development of Egyptology in Western Europe. ${ }^{1}$ The birth of Egyptology as an academic discipline is related to the decipherment of hieroglyphic script and the publication of the results in this research field by French Egyptologist Jean-

\footnotetext{
The author would like to express his gratitude to Vladimir D. Mihajlović and Vera Vasiljević for providing valuable comments on the early form of this paper. The paper is an extended and improved version of the contribution to the catalogue for the exhibition Under the Spotlight. Ancient Egyptian Collections in Museums in Serbia, Matić 2019b.

1 Matić 2011/2013: 38.
} 
François Champollion (1790-1832) in 1822. ${ }^{2}$ Academic interest in ancient Egypt in Serbia can be traced back to lectures on the "history of Misr"3 which were given by Nikola Vulić (1872-1945), historian, classical philologist and an archaeologist, in 1898/1899 at the Great School in Belgrade (in Serbian "Velika škola", which offered the highest level of education from 1863 to 1905 and later becoming a university) as part of his "General ancient history". At the Department of Archaeology at the Faculty of Philosophy, University of Belgrade, Dušan Glumac (1899-1980), philologist, historian, and archaeologist, was the first to lecture on ancient Egypt in 1955/1956.

One of the reasons for little or almost non-existent interest in the ancient Egyptian past before the establishment of archaeology as an academic discipline is certainly the fact that Egyptology was developed in western European colonial encounters with Egypt during the nineteenth century. ${ }^{6}$ In that time, Serbia was slowly but surely freeing itself from Ottoman rule and becoming a young nation state by the decision of The Congress of Berlin (13 June - 13 July 1878). Thus, research interest in ancient Egypt and Egyptology was marginal in comparison to national history and the focus on the establishment of the new nation state and the later "the ethnogenesis of Yugoslavs". This is nicely demonstrated by the definition of the research goals of later Yugoslav archaeology, as laid out at the first meeting of Yugoslav archaeologists from 3 to 8 May $1950 .^{7}$

However, although there was not much academic interest in ancient Egypt, the land of Egypt evoked the interest of pilgrims from what is now modern Serbia in the Middle Ages but also later. ${ }^{8}$ Non-academic interest in ancient Egyptian past on the territory of modern northern Serbia (Vojvodina), which was then a territory of Austro-Hungarian empire, appeared already at the end of nineteenth century when the first travellers who went to Egypt brought Egyptian antiquities back as souvenirs. Among them were Wilhelm Wettl, a printer and publisher from Vršac, and Max Adler, a citizen of Vršac, who donated the antiquities his brother Joseph Adler brought from Egypt to the museum in Vršac. Furthermore, the famous Serbian painter Paja Jovanović; Leonhard Böhm, antiquarian and mayor of Bela Crkva; Jovan Fernbach, famous lawyer and member of Matica srpska9;

\footnotetext{
Hassan 2010: 266; Jeffreys 2003: 5-6.

Misr is romanized Arabic name for Egypt found in many Semitic languages including the oldest evidence in Akkadian.

4 Danijela Stefanović extensively dealt with his manuscript entitled The History of Misr (National Library of Serbia, NLS R 382/1). The manuscript consists of lecturing notes which he had used during the summer term 1898/9. On 48 pages Vulić discussed extensively the issue of absolute and relative chronologies, stressing the importance of Manetho's history and Turin King List; genealogy of the rulers of the 4th Dynasty; canonical and non-canonical nature of Egyptian art; the cult of Osiris; the nature of the Hyksos rule, etc. He referred wherever possible to classical writers, i.e. Herodotus and Diodorus. On April 10, 1924 he gave a lecture on the discovery of Tutankhamon's tomb. Stefanović 2014. His importance for the history of Egyptology in Serbia is in shadow.

Matić 2011/2013: 38.

Hassan 2010: 265; Reid 2002: 142.

Milosavljević 2013: 718.

Vasiljević 2016: 175-181.

The oldest cultural and scientific institution in Serbia, founded in 1826 in Pest (today a part of Budapest), and moved to Novi Sad in 1864.
} 
Hadži Pavle Riđički; Jov. Šorak of Rijeka; and Ernest Brummer. ${ }^{10}$ This is how the collections in museums in Belgrade, Vršac, Sombor, and Subotica acquired Egyptian antiquities that were later studied and published. In fact, collecting Egyptian antiquities on travels and presenting them to local museums was a western and central European tradition. ${ }^{11}$ This tradition clearly influenced cities with a Serbian population such as Vršac, Sombor, and Subotica within the Austro-Hungarian domain.

The overviews of research history on ancient Near East and Egypt in Serbia until now have focused more on these famous collectors. There is a short overview of the development and state of Egyptology in Serbia ${ }^{12}$ and a detailed study of the reception of ancient Egypt in Serbia. ${ }^{13}$ However, antiquarians did not leave their views of ancient or modern Egypt in written form. Milorad Rajčević and his reception of ancient and modern Egypt were until now not the focus of the few authors in Serbia who dealt with ancient Egypt and its modern reception. ${ }^{14}$ His importance as a travelogue writer has been stressed only recently. ${ }^{15}$

Rajčević was born in 1890 in Prokuplje near Leskovac in southern Serbia, where he finished four classes of elementary school and two classes of Građanska škola (civil school). He was interested in painting, travelled to Vienna, and visited Salzburg, Munich, Stuttgart, Nuremberg, Ulm, Paris, Geneva, Lausanne, Bern, Zurich, Basel, and Lucerne. He also travelled to the USA, and in 1910 he met the editors of the Belgrade journal Mali žurnal (Little Journal) who in the form of a bet offered him two years, a prize of 10,000 dinars, and a monthly payment of 150 dinars to travel through Europe, Asia, America, and Africa. He was supposed to wear the uniform of the Serbian infantry on his journey and provide evidence of his visits by getting confirmation from local authorities. ${ }^{16}$ The director of Mali žurnal at that time was Pera Savić, one of the Savić brothers (Mihajlo, Božidar, Pera, and Svetolik). The brothers owned a print shop, a book shop, a cinema, and a pastry shop in Belgrade. ${ }^{17}$ Rajčević started his world travel on 14 March 1910; however, he did not visit Africa until after the First World War (1914-1918). He described his journeys in his travelogues Iz žarke Afrike (Under the African Sun) in two volumes from 1924 and 1925 and $\mathrm{Na}$ dalekom istoku (In the Far East) from 1930. ${ }^{18}$ The journey to Egypt is described in the first volume of the travelogue Under the African Sun and this volume is also the focus of this paper. Rajčević died in Lübbecke (Germany) in $1964 .{ }^{19}$

As stated at the beginning of this introduction, the first academically educated historians and archaeologists in Serbia at the end of nineteenth century did not show interest in studying ancient Egypt, and the first focused university lectures in this field appeared

10 Anđelković 2002a: 212; Anđelković 2002b: 47; Anđelković and Panić-Štorh 2002: 9-11; Anđelković 2007; Anđelković and Harker 2011: 718; Anđelković and Elias 2013; Prodanović Bojović 2019; Vasiljević 2014; Vasiljević 2016: 205-207.

1 Novaković 2014: 36; Tomorad 2015; Šćukanec Rezniček 2015: 85.

12 Matić 2011/2013.

Vasiljević 2013; Vasiljević 2016.

Matić 2019b; $c f$. Vasiljević 2016: 219.

Savković 2018.

Dimitrijević 2015; Savković 2018: 517-519.

http://www.politika.rs/scc/clanak/365428/Braca-Savic-srpska-braca-Limijer

Rajčević 1924, 1925, 1930.

Savković 2018: 515. 
relatively late, namely in 1950s. Therefore, it is interesting to ask what the experiences of Serbian travellers to Egypt at the beginning of twentieth century had, and what their views on ancient Egypt were. Were their views close to the Orientalist and colonial views prevalent in western Europe of that time? ${ }^{20}$ Or can we trace local specific trends of reception and its academic background $?^{21}$ As was already emphasized, in an environment devoid of colonial experience we can equally find imperialistic representations, textualizations, interpretations, contextualizations, and politizations as in imperial environment. ${ }^{22}$ In this we should not forget the context of the ideas expressed by Rajčević, namely that of a travelogue, as the written word on the Other lands meant to describe certain experiences and to represent both their imaginary dimensions and political reality. ${ }^{23}$ Egypt is in this context particularly interesting as it seems that by the end of nineteenth century almost every European or American traveller who visited this country wanted to write down his or her experiences, no matter the number of already existing travelogues. ${ }^{24}$ These travelogues were written not only by members of a specific social class but were also aimed at a specific social class.

Still, non-academic views are no less discursively formed than academic ones, and academic views are no less political than non-academic ones, so the question is in which measure are non-academic views close to the academic ones and are they formed by the same discourses? ${ }^{25}$ As stated by postcolonial theoretician Homi Bhabha, to accept that there are many forms of political writings, whose effects can easily be lost if they are divided into theoretical and activist, or one can say academic and non-academic, is a sign of political maturity. Both forms of writing are forms of discourse. ${ }^{26}$ Reading Rajčević's travelogue of can help us to uncover ideas about ancient Egypt in Serbia before the appearance of academic interest in it. Reports from his travels were successively published in several important journals of his time, such as Mali žurnal, for which he wrote from 1910 to 1930. These reports were then published as the monograph travelogue Under the African Sun (1924 and 1925). ${ }^{27}$ Therefore, we can propose with relative certainty that his experiences in Egypt and impressions of modern and ancient Egypt reached a wider audience and formed knowledge and attitudes. This is especially the case because the journal was meant for the bourgeois class, which had the power to form public opinion. Mali žurnal was a famous oppositional journal with a radical and later democratic orientation.

The goal of this paper is to contextualize the representations of modern and ancient Egypt from Rajčević's travelogue, and to, when and if possible, place them in the frame of well-established "common places", understood as then widespread and accepted ideas originating in academia but found also in non-academic circles. This paper contributes to an understanding the perception of ancient and modern Egypt in Serbia (then part of the Kingdom of Serbs, Croats, and Slovenians) at the end of the first quarter of twentieth

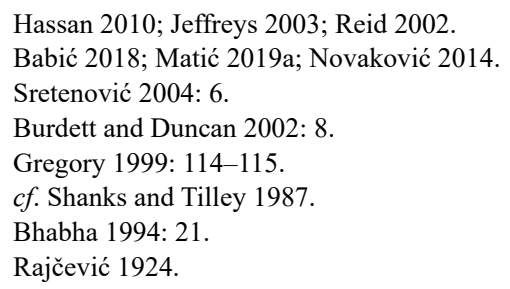


century. In this sense this task is important because it demonstrates the necessity for academic studies of ancient Egypt and its reception in Serbia. ${ }^{28}$ This also means providing an expert critique on the ideas on ancient Egypt both in the academic and non-academic communities. ${ }^{29}$ Attention here is given to Rajčević's experiences and thinking, since they demonstrate that, at first glance, harmless "common places" have a clear ideological context. This is why this is also a contribution to rethinking "common places" in the development of attitudes towards the Near East in Serbia. The rethinking of "common places" gained increased focus in Serbian archaeology only in the last two decades and it is of crucial importance. ${ }^{30}$

Under the African Sun was published by Grafički zavod Makarije (Makarije Graphic Bureau) in Belgrade in 1924. The hardcover book contains 237 pages of text in the Cyrillic script and is illustrated with black and white photographs and colour drawings. It was translated to French under the title Sous le soleil de l'Afrique and self-published by the author in Romania in 1931. Only a segment of this book is about ancient and then modern Egypt. For the most part the book is dedicated to Rajčević's travels; however, the reader occasionally comes across his assessments and opinions, which are not given as an integral whole but provide a very adequate illustration of his views and attitudes toward Egypt and its past. All such relevant passages will be analysed further. I follow the opinion of Dejan Sretenović, who argued that the first Serbian travellers to Africa viewed this continent through the filter of imperialist episteme, so that the knowledge they formed on Africa was based on colonial literature. ${ }^{31}$ Since Rajčević does not quote any specific authors in his monograph, it is important to trace possible sources of inspiration for his ideas, if it is not possible to reconstruct with great certainty the actual authors who influenced him.

\section{Wild Europe and Ancient Egyptian Civilization}

With the rise of Egyptology as an academic discipline whose object of research is ancient Egypt, a clear border was drawn between the pharaonic and Graeco-Roman history of Egypt and the Medieval Islamic past of Egypt. Although criticized, this division is still common. ${ }^{32}$ One of the reasons for this division is the European idea of ancient Egypt being a civilization developed by a white race and comparable to the civilizations of Greece and Rome. ${ }^{33}$ This colonial understanding of ancient Egypt is nicely illustrated on the cover of the monograph Description de'l Egypt, published in twenty-three volumes from 1809 to 1818. Here the landscape of Egypt is depicted without Islamic monuments, architecture, or traces of life. Instead, the monuments from pharaonic and Graeco-Roman Egypt dominate. On the very top is a representation of Napoleon Bonaparte in the form of Alexander the Great riding a chariot and attacking the Mamelukes. ${ }^{34}$ In this image, Napoleon is the new Alexander and

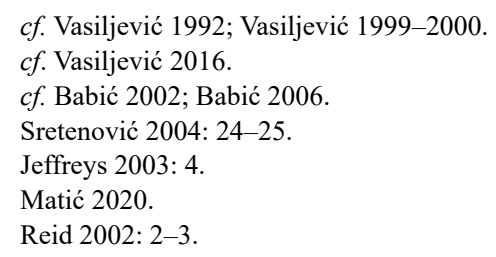


Mamelukes are the new Persians. A clear message was sent of both Napoleonic and European domination and the return of Egypt to the civilizational realm from which it was cut out either by the Persians or from the Mamelukes. In this context, it is important to mention Napoleon's message to the people of Alexandria on 2 July 1798 in which it is stated that French soldiers are the real Muslims: "nous sommes les vrais musulmans". ${ }^{35}$

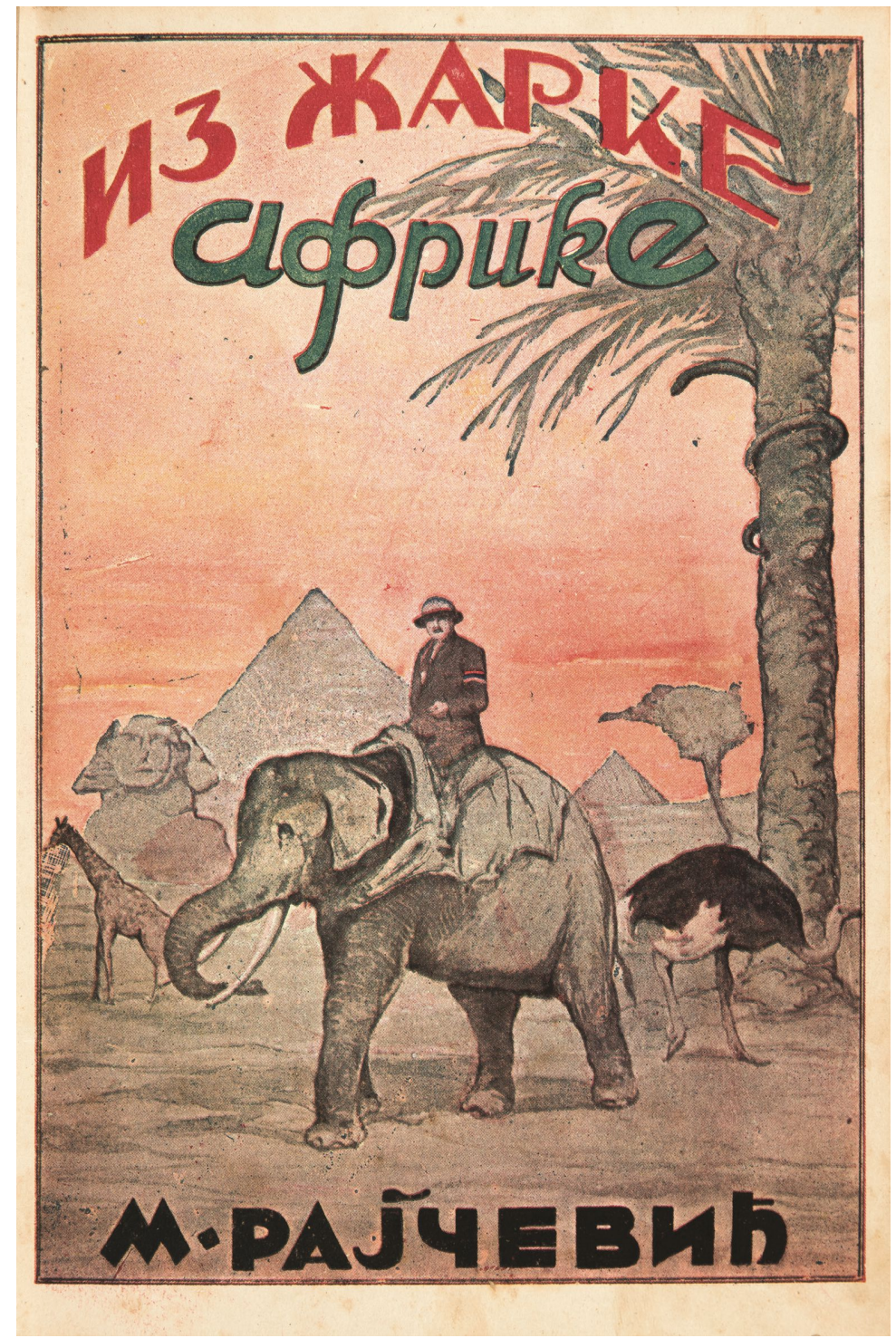

Fig. 1. Milorad Rajčević in an African landscape (Рајчевић 1924). 
European empires such as France and Great Britain colonized both modern and ancient Egypt. Egypt and other Islamic countries were understood as "live province, the laboratory, the theatre of effective western knowledge about Orient" ${ }^{36}$ Egypt was for the later travellers like a theatre or exhibition in situ, as there they can see the glorious monuments of the past and the easterners they read about in novels. ${ }^{37}$ Travelers in the age of modernity developed attitudes toward modernity through their travels understood as progress, national cultural identity, norms, and values. In this process, certain ancient cultures, namely the ones which developed in the countries they visited such as Egypt, are often valued more than modern ones and the view of the past is nostalgic. ${ }^{38}$ Present occupants of these lands are considered not worthy of them in comparison to the glorified cultures which were there before them.

Just as the colonial idea of Egypt in Description de'l Egypt is summarized with its cover, so is the idea of Africa and Egypt nicely summarized in Rajčević travelogue in one of the illustrations from the book. There the landscape of Africa is depicted using a number of colonial tropes (Figure 1). Rajčević is shown here riding an elephant and dressed in the typical British colonial officer's clothing, while in the background there are images of giraffes, an ostrich, and a palm tree with a snake coiled around it. A savannah acacia, a Sphinx, and two of the Giza pyramids are also visible in the distance. Like in Description de'l Egypt, the representation of Rajčević in an African landscape is a colonial hybrid image which has little to do with reality as a whole, but it relies on reality through references to its elements. ${ }^{39}$ Although the Savić brothers wanted him to wear the uniform of Serbian infantry on his travels, Rajčević was depicted in an entirely different manner in his travelogue. This image of Rajčević was related to the image of the Egypt he described in his travelogue.

European academia had slowly but surely defined Egypt as the cradle of civilization, and in this context the most drastic monocentric hyper-diffusionist views are found in the work of Grafton Elliot Smith (1871-1937), an Australian-British anatomist and Egyptologist. More specifically, monocentric hyper-diffusionism implies the idea of the rapid spread of cultural and civilizational traits that supposedly emerged in one place and spread out from it. ${ }^{40}$ The idea of ancient Egypt's cultural and civilizational dominance were so engrained that they were found also outside of academic circles. Thus, we also find them in the Rajčević's travelogue:

History repeats itself and it can be rightfully said that everything has happened before. In Europe we work, fumble, discover. We invent something, and then after a while the remains of olden times show that it already existed before. While we debate in Europe, for instance, about which of our modern nations was the first to wear gloves, and what those gloves looked like, the latest discovery of the tomb of Pharaoh Tutankhamun in Egypt reveals that gloves were worn in Egypt in an age in which we Europeans went about as savages, not only without gloves, but even, perhaps, without shirts. Our ladies, idle and totally free to think up fashion 'novelties', considered it an extraordinarily new and delightful thing to walk on the street with their dogs; however, from the depictions that are found

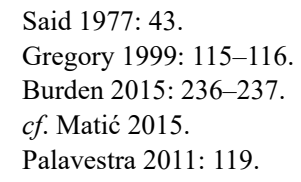


here it is evident that ancient Egyptian women had already done that very same thing. The life of mankind is a closed trajectory, on which we move along, without knowing much about where we came from or where we are going. ${ }^{41}$ (emphasis by the author).

The attitude expressed by Rajčević that history repeats itself and that everything already happened indeed resembles the "doctrine of survivals" of cultural evolutionist Edward Burnet Tylor (1832-1917); that is, the idea that cultural tendencies in the development of human societies are always similar. ${ }^{42}$ Rajčević further mentions the 1922 discovery of the tomb of Tutankhamun (KV 62) by Egyptologist Howard Carter (1874-1939) and the gloves found in the tomb. These serve him as an argument to distance the developed civilized world of ancient from wild ancient Europe. The equation of savagery with nudity found in Rajčević's writings is typical for colonial images of the Other that are projected onto the European past with the goal of pointing toward European progress and distance from savagery as the lowest stage in socio-cultural evolution. ${ }^{43}$ He concludes that humanity is on a closed path and adds:

Egyptian history begins at a time when we do not even know whether we went around naked or clothed in Europe. At 3400 years before Christ, which is saying almost five and a half thousand years ago, Egyptians had one state and one king - Menes, who managed to form a political unit out of disassembled provinces. In those times, the Egyptian people already knew about state administration, courts, faith, tombs. The truth is that their faith was primitive and very much resembled our beliefs, which appeared maybe two or three thousand years later, or the present-day beliefs of some negro tribes from Central Africa and the Eskimos from the polar regions. ${ }^{44}$ (emphasis by the author).

That some societies distant in space are related through a common denominator such as "primitive" is also typical for socio-cultural evolution and European colonialism. Nudity is again taken as an important category of value, and the category of time is introduced with the goal to point towards socio-cultural position of ancient Egypt as elevated. When religion is concerned, time is introduced in the form of analogy with certain modern societies such as African tribes and Eskimos, with the goal to distance from these through distancing from the "primitive". Here we should remind ourselves of the words written by Tylor:

The educated world of Europe and America practically sets the standards by simply putting its own nations on one end of the social ladder, and the savage tribes on the other end, arranging the rest of the humanity between these ends, depending on whether it is closer to a savage or a cultured way of life. The basic criteria of classification are the existence or absence, i.e. the high or low development of industrial skills, especially metallurgy, the production of tools and utensils, agriculture, architecture (etc.), the scope of scientific knowledge, the elaboration of moral principles, the circumstances surrounding religious beliefs and ceremonies, the level of social and political organisation, etc. Some would deny that the following races are properly listed according to cultural order: Australians, Tahitians, Aztecs, Chinese, Italians. ${ }^{45}$

\footnotetext{
Rajčević 1924: 101.

Tylor 1903: 33.

Milosavljević 2011: 616-620.

Rajčević 1924: 102-103.

Tylor 1903: 27.
} 
However, not even early Egyptology was isolated from such views of the Other or from similar classifications of communities on the socio-cultural evolution ladder. ${ }^{46}$ Thus, Rajčević also makes commentaries about the contemporary Egyptian population:

\begin{abstract}
Although the Arabian town-dwellers are very agile and industrious, and even very free-minded, still one will find among them the mysticism and particular inclination toward daydreaming which is found among all eastern peoples. However cultured, Arabs are still fatalists who believe in destiny, which in many ways interferes with their trade activities, in which Europeans are overtaking them so soundly. ${ }^{47}$
\end{abstract}

A generalisation like this, in which Rajčević ascribes to Arabs mysticism as a specific way of thinking distinctive from all eastern peoples, is a familiar and frequent Orientalist topos. The rationalisation of western systems of thought concurrently led to the mystification of eastern systems of thought. ${ }^{48}$ In the thirty-fourth chapter of his two-volume work Modern Egypt, Evelyn Baring, the first Earl of Cromer names lack of precision as the main feature of the Oriental spirit. While the European is a natural logician and sceptic, the Oriental lacks symmetry and his way of thinking is sloppy. The descendants of Arabs allegedly suffer from a deficiency of logical faculty. ${ }^{49}$

Rajčević compares the cultural, civilisational and technological supremacy of Egypt with Europe in the middle of the fourth century B.C.E. ${ }^{50}$ According to Rajčević, Egypt has degraded from its glorious pharaonic past to contemporary Islamic Egypt which is (was) under Great Britain's colonial rule. Hence, his attitudes are not far removed from the ideas on which the original European deliberations regarding Egypt's past, and likewise its present, were based. As mentioned in the introduction, H. Bhabha argued that all forms of writing are forms of discourse. Rajčević's views can be characterized as colonial discourse, which he takes over from unknown authors and as widely accepted perspective about the Orient, Egypt, its past, and the European present.

\title{
3. The Body of an Arab and the Body of an Ancient Egyptian
}

The colonial image of the Other can essentially be understood through an understanding of attitudes toward the corporeal. ${ }^{51}$ In the middle of the nineteenth century, the discourse of intolerant racism, which drew fixed biological boundaries between human groups, was consolidated in European reflections on mankind. ${ }^{52}$ Racial criteria were derived from European aesthetic criteria, among others. ${ }^{53}$ Hence, Rajčević makes racialist comments on the body of the Other: "because a man cannot keep company with negro women since they smell',54

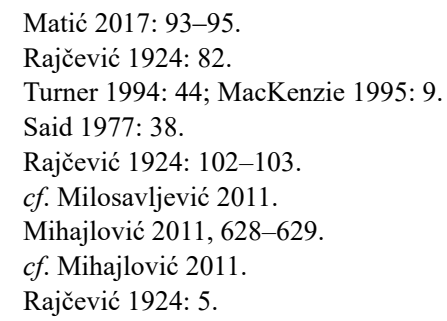




\begin{abstract}
Also:
Since the fellah spends his time in the sun and the field, his skin is much darker than that of the townsfolk of the same race. Moreover, not all fellahs are equal, even if they have no admixture of other races: the more one travels south, the darker their skin gets, therefore, at the mouth of the Nile, the fellah is light brown, while in Upper Egypt, beyond Cairo, the skin colour is dark and looks like bronze. Even there, where the Arabian population is mixed with the Nubians who are completely black, there is a great difference in colour. This difference is discernible even between the genders, thus the drawings from old times show women with faces painted red, and the men with a darker skin tone. This is explained by the fact that women stay indoors more than men, and genuinely have lighter skin than them. Moreover, their lighter skin is one of their beauty traits, a source of vanity and female pride. ${ }^{55}$ (emphasis by the author).
\end{abstract}

Rajčević's commentary on the differences in skin colour is particularly interesting because he refers to visual representations from Ancient Egypt, in which men are depicted as darker (brown red), and women with a lighter complexion (light yellow). The explanation that Rajčević offers is that women are less exposed to the sun, since they supposedly spend more time at home. Bearing in mind that Rajčević explicitly cites Herodotus' description of Egypt $^{56}$, it is surprising that he neglects the his account of the gender labour division (Hdt, II, 35), wherein women are the ones who work in the market engaging in trade and jobs that are carried by men in the Greek world. ${ }^{57}$ The question here is what Rajčević chooses as his explanation, while the answer is to be found in yet another of the many Orientalist interpretations of Ancient Egypt. Namely, he indirectly transposes the gender labour division of modern (from his perspective) Islamic Egypt to Ancient Egypt through an analogy with the visual depictions of genders. The framework of such an interpretation is most certainly Orientalist. Available research indicates that the difference in skin complexion between the sexes is not always present in pictorial representations (e.g. servants of both sexes in the household depicted with the same skin colour). The dark skin tone has a visually stronger effect on the observer and attracts their attention to the male figures and not the female ones, which is most likely linked to the general prevalence of men in Egyptian depictions. ${ }^{58}$ His previously quoted comment on idle European ladies who develop new fashion trends is also at the same time a statement on gender.

His other comments on Arabs also demonstrate his racial attitudes:

\begin{abstract}
As we are on the topic of Arabs from Egypt, then I should at least give a few words on Arabs, population of the towns, because this a class with which I had most contact with. These Egyptian citizens represent maybe the most unclean part of Arabic race. Among them one can notice almost all variations in skin colour from white European to a negro from central Africa. This comes from the fact that citizens of Egypt are in constant contact with most different races with whom they mixed blood. Arab-European or Arab-Negro are here a. common thing and it is clear that children born from such marriages have to be very strange also in skin colour..$^{59}$ (emphasis by the author)
\end{abstract}

Also, "Because Arabs are very dirty people; he bathes in his own sweat and his shirt is so

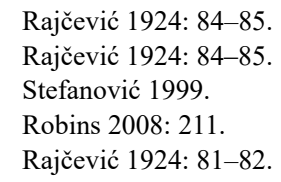


sticky and greasy that it is not possible to guess its original colour". ${ }^{60}$

Rajčević's attitudes on cleanness and dirt are also not strange to Orientalist establishments of borders between western bodies and bodies of Others. Namely, dirt is a visible index of difference and a method of stigmatisation of the Other as it is often associated with deviation. ${ }^{61}$ As anthropologist Mary Douglas wrote in a monograph, attitudes on dirt express symbolic systems and dirt is that which is not supposed to be included in the pattern which is to be preserved. ${ }^{62}$ Binary opposition between the dirty Arab and the clean European is framed by negative attitudes to dirt, and it places the European in the frame of positive and excludes the Arab from European body patterns. Such images of the dirty Other are found in other colonial contexts too, such as British India. ${ }^{63}$

\section{Conclusion}

Under the African Sun (1924) is a travelogue filled with imperial and colonial attitudes toward the Other. These attitudes are particularly evident when considering Rajčević's views of (from his perspective) ancient and modern Egypt. This stance has obvious parallels in Egyptological and archaeological ideas about the Egyptian past and civilisation. The same way that the early Egyptologists drew a boundary between the pharaonic and Graeco-Roman past and the medieval ("Islamic") past, and therefore the present, within the same discourse, so does Rajčević also draw a line between the old and the modern (from his perspective) Egypt. For Rajčević, Ancient Egypt is a civilisation that far surpassed the societies in Europe that were contemporary to it, whereas the Egypt that he refers to as modern had been downgraded. Such a view of old and modern Egypt is clearly connotative of late-nineteenth and early-twentieth century colonial discourse and does not differ from the academic narrative of the time of ancient and modern Egypt.

Rajčević's modern Egypt is a land of mysticism and unclean people. His views of Arabs and modern (from his perspective) Egypt have an evident Orientalist pretext. Bearing in mind the readership of Rajčević's travel book and the bet he made with the editors of Mali žurnal, it may be concluded that his book was written with a view to attract attention, surprise, stun, and shock the Serbian public. Rajčević's Africa, and even Egypt, thus becomes a landscape of the peculiar and the extraordinary, wherein Rajčević is the Serbian Phileas Fogg, who began his journey Around the World in Eighty Days in Egypt. ${ }^{64}$

Still, we must not overlook the power that written media had in shaping knowledge and public opinion in Rajčević's time. The ideas that Rajčević presents were ingrained and omnipresent among the European bourgeoisie and elite circles of the times, regardless of whether their members were experts in researching the past or simply curious people, irrespective of their level of expertise. Probably through contact with western European friends, acquaintances, and literature, Rajčević uncritically and by default accepted the

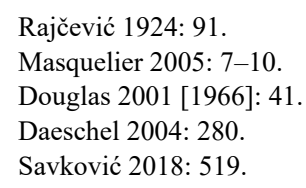


attitudes regarding ancient and modern (from his perspective) Egypt. In a certain way, he was a translator of Egyptian culture for the Serbian public based on his personal view, which was formed within a "colonial" frame. In this manner, Rajčević defines both his Serbian audience as "European" and the object of his travelogue as the Orient. As Europe was imagining and othering the Balkans ${ }^{65}$, Rajčević as the Serbian Phileas Fogg was loosening these differences by othering ancient and modern Egypt in the same manner as western Europeans.

The question of his sources remains largely unresolved because, although inherited ideas such as socio-cultural evolution, progress, doctrine of survivals, and racial approach to ancient and modern populations etc. could have been traced, no exact sources could be pinpointed. One possible source of information could have been Baedeker or similar guides for travellers. Beginning in the 1830s, the Karl Baedeker firm in Germany started publishing such guides. Two volumes were published on Egypt, one in 1877 and one in 1891. However, except mentioning, for example, the difference in skin colour between men and women in ancient Egyptian art, these Baedeker guides do not offer an explanation given by Rajčević in his travelogue.

One has to bear in mind though, that there are cases of incorporating theories and methods in scientific practice in the west into the scientific practice in Serbia (then Kingdom of Serbs, Croats and Slovenians or later Yugoslavia) through the education of Balkan intellectuals in western and central Europe. Some examples are the racial approach of anthropologist Niko Županić (1876-1961) ${ }^{66}$ and (pre)historian Borislav Jankulov (1878$1969)^{67}$, which also meant uncritically taking over colonial and imperial attitudes of those who developed these theories and methods in the first place. Although Rajčević was not educated at the university level, he did visit western and central European cities and travelled to America. Certain ideas were omnipresent and ingrained in European bourgeois and elite circles during the time Rajčević wrote his travelogue, no matter if the members of these circles were experts on the past or just interested people of different career profiles. It is possible that ideas which could be traced through this analysis of the travelogue Under the African Sun find their way through knowledge exchange in informal bourgeois circles wherever he went.

\section{REFERENCES:}

Anđelković, B. 'Staroegipatska zbirka Narodnog muzeja u Beogradu', Glasnik srpskog arheološkog društva, 18, 2002a, 211-224.

'Egyptian Antiquities in the Museums of Serbia', in: M. Eldamaty and M. Trad (eds.), Egyptian Museum Collections around the World. Studies for the Centennial of the Egyptian Museum, Cairo. Volume One, Cairo: Supreme Council of Antiquities, 2002b, 39-50.

. 'Staroegipatska zbirka Gradskog muzeja u Somboru', Glasnik srpskog arheološkog društva, 23, 2007, 227-244.

\footnotetext{
Todorova 1997.

Milosavljević 2013.

Mihajlović 2017.
} 
Anđelković, B. i Panić-Štorh, M. Staroegipatska zbirka Gradskog muzeja u Vršscu. Vršac: Gradski muzej Vršac, 2002.

Anđelković, B. and Harker, J. 'Identity Restored: Nesmin's Forensic Facial Reconstruction in Context', Etnoantropološki problem, 3.6, 2011, 715-728.

Anđelković, B. and Elias, J. P. 'Ernest Brummer and the Coffin of Nefer-renepet from Akhmim', Etnoantropološki problemi 8.2, 2013, 565-584.

Bhabha, H. The Location of Culture. London and New York: Routledge, 1994.

Babić, S. 'Still innocent after all these years? Sketches for a social history of archaeology in Serbia', in: P. F. Biehl, A. Gramsch und A. Marciniak (Hrsg.), Archäologien Europas: Geschichte, Methoden und Theorien, Münster: Waxmann, 2002, 309-322

. 'Archaeology in Serbia-A Way Forward?' in: N. Tasić and C. Grozdanov (eds.), Homage to Milutin Garašanin, Belgrade: Serbian Academy of Sciences and Arts, 2006, 655-659. . Metaarheologija. Ogled u uslovima znanja o prošlosti. Beograd: Clio, 2018.

Bädeker, K. Ägypten: Handbuch für Reisende. Band 1. Unter-Aegypten bis zum Fayûm und die SinaiHalbinsel. Leipzig: Karl Bädeker Verlag, 1877. Ägypten: Handbuch für Reisende. Band 2. Ober-Aegypten und Nubien bis zum zweiten Katarakt. Leipzig: Karl Bädeker Verlag, 1891.

Burden, R. Travel, Modernism and Modernity, London and New York: Routledge, 2015

Burdett, Ch. and Duncan, D. 'Cultural Encounters: European Travel-Writing in the 1930s' in: Ch. Burdett and D. Duncan (eds.), Cultural Encounters: European Travel Writing in the 1930s, New York and Oxford: Berghahn Books, 2002, 1-10.

Champion, T. 'Egypt and the Diffusion of Culture', in: D. Jeffreys (ed.), Views of Ancient Egypt since Napoleon Bonaparte: Imperialism, Colonialism and Modern Appropriations, London: University College of London Press, 2003, 127-146.

Daeschel, M. 'The Civilizational Obsessions of Ghulam Jilani Barq', in: H. Fischer-Tine and M. Mann (eds.), Colonialism as Civilizing Mission: Cultural Ideology in British India, London: Anthem Press, 2004, 270-290.

Douglas, M. Purity and Danger. An Analysis of the Concepts of Pollution and Taboo. London and New York: Routledge, 2001 [1966].

Díaz-Andreu, M. A World History of Nineteenth-Century Archaeology: Nationalism, Colonialism, and the Past, Oxford: Oxford University Press, 2007

Dimitrijević, N. Leskovac 101. 6000 p.n.e-1945. god. Leskovac: Đak, 2015.

Gregory, D. 'Scripting Egypt: Orientalism and the Cultures of Travel', in: J. Duncan and D. Gregory (eds.), Writes of Passage: Reading Travel Literature, London: Routledge, 1999, 114-150.

Hassan, F. A. 'Egypt in the Memory of the World', in: W. Wendrich (ed.), Egyptian Archaeology, Oxford: Blackwell, 2010, 259-273.

Jeffreys, D. 'Introduction-Two Hundred Years of Ancient Egypt: Modern History and Ancient Archaeology', in: D. Jeffreys (ed.), Views of Ancient Egypt since Napoleon Bonaparte: Imperialism, Colonialism and Modern Appropriations, London: University College of London Press, 2003, 1-18.

MacKenzie, J. M. Orientalism. History, theory, and the arts. Manchester and New York: Manchester University Press, 1995

Matić, U. 'Slike faraonske prošlosti: O razvoju i stanju egiptologije u Srbiji', in: E. Epštajn (ed.), Egipat u sećanju Srbije, Beograd: Muzej afričke umetnosti. 2011/2013, 29-46. https://www.museumofafricanart.org/images/publications/Epublications/Egipat_u_secanju_Sr bije_e_izdanje.pdf, pristup Jun 2, 2018

'Pyramids, dragons and whores: (Post)colonial myths and metafictions in "A Song of Ice and Fire" novels by G. R. R. Martin', in: B. Hinson and B. Janulikova (eds.), Archaeology: Myths 
within and without, Cambridge: Archaeological Review from Cambridge, 2015, 172-184.

Matić, U. 'Der "dritte Raum", Hybridität und das Niltal: Das epistemologische Potenzial der postkolonialen Theorie in der Ägyptologie', in: S. Beck, B. Backes und A. Verbovsek (Hrsg.), Interkulturalität: Kontakt - Konflikt - Konzeptualisierung: Beiträge des sechsten Berliner Arbeitskreises Junge Aegyptologie (BAJA 6). Göttinger Orientforschungen IV. Reihe: Ägypten. Band 63, Wiesbaden: Harrassowitz Verlag. 2017, 93-111.

. 'Review of Staša Babić. Metaarheologija. Ogled o uslovima znanja o prošlosti (Beograd: Clio, 2018, 188pp., ISBN 978-86-7102-596-6)', European Journal of Archaeology, 22.2, 2019a, 289-293.

. 'Memories under the African Sun. An Overview of Milorad Rajčević's Journey to Egypt', in: E. Epštajn (ed.), Under the Spotlight. Ancient Egyptian Collections in Museums in Serbia. Belgrade: The Museum of African Art-the Veda and Dr. Zdravko Pečar Collection, 2019b, 83-94. . Ethnic Identities in the Land of the Pharaohs. Past and Present Approaches in Egyptology. Elements-Ancient Egypt in Context. Cambridge: Cambridge University Press, 2020.

Mihajlović, V. 'Kanonski lepo-estetski kriterijumi i geneza rasizma'. Etnoantropološki problemi 6.3, 2011, 625-640.

Mihajlović, V. D. 'Borislav Jankulov, kultura sećanja i tumečenje praistorije I: rasiološki pristup prošlosti', in: M. Samardžić (ur.) Kultura sećanja na vojvođanskom prostoru, Novi Sad: Filozofski fakultet, 2017, 71-99.

Milosavljević, M. 'Divlji čovek kao mera drugosti', Etnoantropološki problemi 6.3, 2011, 607-624.

. 'Niko Županić i konstrukcija jugoslovenske etnogeneze', Etnoantropološki problemi 8.3, 2013, 717-746.

Novaković, P. Historija arheologije u novim zemljama Jugoistočne Evrope, Sarajevo: Univerzitet u Sarajevu, 2014.

Palavesta, A. Kulturni konteksti arheologije. Beograd: Filozofski fakultet, 2011.

Prodanović Bojović, A. 'From Egypt to Serbia. Creating Ancient Egyptian Collections', in: E. Epštajn (ed.), Under the Spotlight. Ancient Egyptian Collections in Museums in Serbia. Belgrade: The Museum of African Art-the Veda and Dr. Zdravko Pečar Collection, 2019, 15-36.

Rajčević, M. Iz žarke Afrike. Uspomene Milorada Rajčevića, svetskog putnika I. Beograd: Grafički zavod Makarije, 1924

. Iz žarke Afrike. Uspomene Milorada Rajčevića, svetskog putnika II. Beograd: Grafički zavod Makarije, 1925.

. Na Dalekom Istoku. Beograd: Štamparija Đura Jakšić, 1930.

Reid, D. M. Whose Pharaohs? Archaeology, Museums, and Egyptian National Identity from Napoleon to World War I. Berkeley and Los Angeles: University of California Press, 2002.

Said, E. Orientalism. London: Penguin Books, 1977.

Savković, N. N. Putovanje-životna opcija Milorada Rajčevića. Filolog, IX, 2018: 514-530.

Sretenović, D. Crno telo, bele maske. Beograd: Muzej afričke umetnosti, 2004.

Stefanović, D. 'Market-women and Market-place in Pharaonic Egypt: According to Hdt, II, 35, Egyptian Written Sources and Iconography', Glasnik srpskog arheološkog društva, 15-16, 1999, 145-151. . 'Serbian encounters with Egypt: Jelena Dimitrijević (1862-1945) and Nikola Vulić (18721945)' unpublished manuscript of the lecture given on 16. 10. 2014, at Kunsthistorisches Museum Wiem - monthly lectures by Egypt and Austria Society.

Šćukanec Rezniček, P. 'The Egyptian Collection in the Archaeological Museum in Zagreb: History and Research', in: M. Tomorad (ed.), A History of Research into Ancient Egyptian Culture Conducted in Southeast Europe. Archaeopress Egyptology 8. Oxford: Archaeopress, 2015, 85-92.

Tomorad, M. 'The Ancient Egyptian Antiquities in Institutional and Private Collections in Croatia', in: M. Tomorad (ed.), A History of Research into Ancient Egyptian Culture Conducted in 
Southeast Europe. Archaeopress Egyptology 8. Oxford: Archaeopress, 2015, 85-92.

Turner, B. S. Orientalism, Postmodernism and Globalism. London: Routledge, 2004.

Tylor, E. B. Primitive culture, researches into the development of mythology, philosophy, religion, language, art and custom. Vol, I. London: John Murray, 1903.

Vasiljević, V. 'Iskrivljena slika starog Egipta'. Glasnik srpskog arheološkog društva 8, 1992, 159-163.

. 'Egiptologija kod nas-luksuz ili potreba?' Glasnik srpskog arheološkog društva, 15-16,

1999-2002, 97-301.

. 'Stari Egipat u našem kulturnom nasleđu?' Etnoantropološki problemi 8.3, 2013, 825-844.

. 'Enterijer kairske kuće na slikama Paje Jovanovića', Znornik Narodnog Muzeja-Beograd

XXI/2, 2014, 205-220.

. Senka Egipta. Beograd: Dosije, 2016.

http://www.politika.rs/scc/clanak/365428/Braca-Savic-srpska-braca-Limijer, accessed on $2^{\text {nd }}$ June, 2018.

\section{УРОШ МАТИТ}

Аустријска академија наука

Аустријски археолошки институт

\section{ПОСТКОЛОНИЈАЛНА ПЕРСПЕКТИВА ПУТОВАЊА У ЕГИПАТ У ПУТОПИСУ ИЗ ЖАРКЕ АФРИКЕ МИЛОРАДА РАЈЧЕВИЋА}

\section{Резиме}

Милорад Рајчевић, познати српски путник, авантуриста и путописац, ишао је и у Египат 1921. у склопу својих светских путовања. Његови утисци и искуства са ових путовања објављени су у београдском часопису Мали журнал, као и у монографијама Из жарке Африке (1924. и 1925) и На далеком истоку (1930). Ово штиво пружа важан увид у слику коју је српски буржоаски сталеж имао и о древном и о Египту из времена Рајчевићевих путовања. Његове импресије и искуства били су обликовани колонијалним дискурсом европског путника и пренети јавности посредством путописа Из жарке Африке. Стога нам ова књига даје увид у ставове према древном и савременом Египту, и то пре него што су се у Србији појавила академска интересовања за проучавање старог Египта. Овај путопис садржи бројне представе о арапској популацији из перспективе дискурса оријентализма, а са становишта историје и археологије, нарочито су упутни његови коментарио прогресу и модернизацији. У том контексту, важну улогу имају Рајчићеве упоредбе европских са староегипатским културним и техничким достигнућима. У овом раду је анализиран садржај путописа Из жарке Африке употребом постколонијалне перспективе и указано је да и поред тога што се препознају одређене идеје својствене колонијалном светоназору његовог доба, није могуће тачно одредити тачне изворе које је Рајчевић користио.

Кључне речи: Милорад Рајчевић, путопис, Египат, Арапи, дискурс оријентализма, постколонијална перспектива. 